\title{
M'Balia Thomas
}

\section{The problematization of racial/ethnic minority student participation in U.S. study abroad}

\begin{abstract}
Within U.S. higher education, there has been concern expressed about the underrepresentation of racial/ethnic minority students in U.S. study abroad programs. Though as a whole these students participate in study abroad at lower rates than their Caucasian ${ }^{1}$ counterparts, the fact that study abroad participation is even problematized by race/ethnicity (rather than other social categories such as gender, socioeconomic status or field of study) and the manner by which this is done warrant critical investigation. Drawing upon Foucault's concept of problematization $(1984,1988)$, this paper examines the discourses and practices (both discursive and nondiscursive) that mark current study abroad literature in which participation by U.S. undergraduates is tracked, categorized and ranked by race and ethnicity. It further problematizes the taken-for-granted assumptions that masquerade as truths and inhabit the methodological and analytical practices that govern research on racial and ethnic minority students, and in the process, uncovers an overarching code of thought that permeates the literature. Ultimately, this paper seeks to challenge the "truths" and counter the assumptions upon which this code of thought is based by highlighting those voices only marginally recognized in study abroad participation literature. These voices provide a local and contextualized perspective on the factors contributing to the lower rates of participation among one racial/ethnic minority category: African Americans. Although the paper does not take up the topic of language learning in study abroad contexts, it does present the real world challenge of language-in-use. It addresses the material and subject effects that a problematization of study abroad participation by race/ethnicity has on students, research practices, institutional and governmental policies, and the allocation of resources related to language study and the promotion and support of study abroad.
\end{abstract}

Keywords: racial and ethnic minorities, study abroad, problematization, discursive and non-discursive practices, disparity

M’Balia Thomas: University of Arizona, USA. E-mail: mbthomas@email.arizona.edu

1 In the U.S., "Caucasian” ("white”) generally refers to individuals whose racial/ethnic heritage is derived from the people groups of Europe, the Middle East and North Africa. 


\section{Introduction}

Since the 2005 publication of the report from the "Committee on the Abraham Lincoln Study Abroad Fellowship Program” (hereafter, The Lincoln Commission), there has been renewed interest in the underrepresentation of racial and ethnic minority students in U.S. study abroad. ${ }^{2}$ Much of the literature addressing this underrepresentation reports that the levels at which racial/ethnic minority students participate in study abroad "lag[ ] far behind" those of Caucasian students despite the increased presence of the former on U.S. college/university campuses and in foreign language classrooms (Dessoff 2006: 21). While data from Open Doors (IIE 2011) confirms that U.S. racial/ethnic minority students are indeed underrepresented in study abroad, this paper takes a critical stance towards literature that problematizes study abroad participation by race and ethnicity. Following Foucault $(1984,1988)$, I understand problematization to be the historical process by which the combination of discourses and practices (discursive and nondiscursive) associated with a given object of thought - in this case, differences observed in U.S. rates of study abroad participation by race and ethnicity - is constituted as a problem. Specifically, I aim to critique the problematization of study abroad participation by race/ethnicity, illustrating the manner in which this phenomenon has lead to 1) an overstatement of the participation levels of white students in study abroad, 2) an oversimplification and assumed primacy of racial/ethnic identity as a meaningful analytic in monitoring study abroad participation, 3) an overemphasis on disempowering concepts of "barriers", "constraints" and "lack", rather than more empowering notions of "possessing" (different academic priorities) and "having" (alternative educational goals) in investigating factors contributing to the lower levels of study abroad participation among racial/ethnic minority students, and 4) an underestimation of racial/ ethnic-specific discourses related to space and place that shape attitudes and influence decisions to study abroad. Ultimately, this paper seeks to demonstrate the manner in which a problematization of study abroad by race/ethnicity contributes to a general failure in the field to address the weightier issue facing the field of study abroad: that regardless of race, less than $2 \%$ of students enrolled in U.S. higher education participate in study abroad in any year. ${ }^{3}$

\footnotetext{
2 Study abroad, here defined as "study, work, or research (or a credit-bearing internship) that is conducted outside the United States and that awards academic credit toward a college degree" (The Lincoln Commission 2005: 14).

3 This figure is based on the percentage of students enrolled in U.S. study abroad for 2009/2010 compared to the total number of undergraduate and graduate students enrolled in U.S. degreegranting institutions at the Secondary level (Associates level and higher) and participate in U.S. Title IV financial aid programs for the same time period.
} 
In addition to Foucault's practice of problematization, two methodological positions frame this paper. The first draws on the seminal work by Firth and Wagner (1997) who challenged the use of reified, binary categories (such as "native"/"nonnative" speaker) in the theories and methodologies of early second language acquisition (SLA) research. Firth and Wagner demonstrated how the adoption of such a categorization meant that some subjects were represented in discourse in "idealized" ways (often left unquestioned), while others were depicted in "oversimplified", "stereotypicalized" and "defective” ways subordinate to those of the idealized subject (Firth and Wagner 1997: 285). The authors additionally identified the variability and shifting salience of seemingly stable identity categories and the contribution an emic perspective provides in contextualizing the negotiations that occur in interactions and result in varying degrees of relevance of different social identities (Firth and Wagner 1997: 288). The second takes up L.T. Smith's (1999) concept of “colonized methodologies” which posits that methods of "selecting, arranging and presenting knowledge ... privilege[ ] sets of texts, views about the history of an idea, [and] what issues count as significant ..." (Smith, 1999: 36). Such methods are imbued with agendas, discourses, and practices at odds with and often failing to incorporate the situated knowledges and subaltern voices of the populations studied. Further, these methodologies frequently reflect an "othering" of a disempowered minority whose practices are positioned not simply as different, but deviantly so (often in direct comparison to an empowered majority), as well as a lack of reflexivity about the collection of participant data. The adherence to such methods results in the repetition of taken-for-granted patterns of thinking and writing which have material effects on the field (through the policies and practices adopted to address a problem) and subject effects on the objects of study (in terms of the discursive and nondiscursive practices through which individuals are "constituted as particular kinds of subjects") (Bacchi 2012: 3).

In problematizing the focus on race and ethnicity in U.S. study abroad participation, this paper does not take a position against the monitoring of such data; tracking study abroad participation by race and ethnicity does provide a measure of how successfully U.S. study abroad reflects the racial/ethnic diversity within the country outside of its borders. Rather, it seeks to review the body of literature concerned with study abroad participation among U.S. undergraduate students, drawing from institution/government policy reports, conference proceedings, trade and peer-reviewed journal articles, published/unpublished dissertations, and edited books and monographs published between 1990-2012 and uncover the process by which participation by race and ethnicity has emerged as an object of thought to be problematized. It further sets out to explore the assumptions and "truths" - that is, ways of knowing that enter into the realm of 
true or false and are regulated by society - that undergird this literature and give way to colonized methodological practices of studying racial/ethnic minorities that shape the policies and practices adopted in the field. Finally, it closes with a counter-reading of the same literature, presenting discourses that represent African American ways of knowing which provide a local and contextualized perspective on this group's underrepresentation in U.S. study abroad.

\section{Coming to know a thing}

\subsection{Promoting and democratizing U.S. study abroad}

Though members of the U.S.'s racial/ethnic minority groups have traveled and studied abroad throughout the country's history (Beck 1996; Pryor 2008; Evans 2009), their participation in study abroad programs has been increasingly problematized since the late 1980s. This problematization has occurred in parallel with a shift in U.S. study abroad policy toward "promoting and democratizing" participation (The Lincoln Commission 2005: v). This move reflects a general acknowledgement in the field that study abroad traditionally has been the domain of the upper middle class, predominately European-American "female undergraduate majoring in the humanities or social sciences, ... [with] Europe as [the] study travel destination" (Gore 2005:8). Though the call to promote and democratize study abroad is found in "The Lincoln Commission” report, this discourse is actually reflected in three institutional policy documents significant in the field of study abroad that precede it - "Educating for Global Competence: The Report of the Advisory Council for International Educational Exchange” (CIEE 1988), A "National Mandate for Education Abroad: Getting on with the Task" (National Task Force 1990) and “Securing America’s Future: Global Education for a Global Age, Report of The Strategic Task Force on Education Abroad” (NAFSA 2003). Reflecting the realities of economic globalization, increased internationalization of U.S. higher education, and post 9/11 national security concerns, these documents advocate "... for active recruiting, financing and program planning that draw students from a much greater cross-section in society, of economic level and ethnic orientation" (CIEE 1988: 8) in order to generate a study abroad demographic "similar to [that] of the U.S. undergraduate student population" (The Lincoln Commission 2005: xi).

The discourse of promoting and democratizing study abroad found within these reports has defined itself through a strategy that draws upon a theme of "participation" and is expressed in terms of "bodies of participants" who are 
monitored, categorized, compared and ranked according to an increasing number of factors, such as gender, race, field of study and sending institution. This theme likewise appears throughout the body of literature concerned with study abroad participation among U.S. undergraduates and is made available for discursive consumption through several tactics, which include:

1. the citing of numbers and figures: "[t]he number of American students studying abroad has more than doubled, rising from under 100,000 in 1996/1997 to almost a quarter of a million in 2006/2007. ..." (Stroud 2010: 491).

2. the adopting of metaphors of movement: "increased dramatically" (Lewin 2009: xiii), grown "steadily" (Picard et al 2009: 321), "remains negligible" (Salisbury et al 2009: 120).

3. the categorizing and comparing of bodies that do and do not participate: "While U.S. students studying abroad for academic credit reached a record 191,321 . . . most of them were Caucasian women, [m]ale students were outnumbered nearly two-to-one by females[... . ] and members of racial and ethnic minorities lagged far behind Caucasian students. ..." (Dessoff 2006: 2021).

Following the tactic of categorizing bodies that do and do not participate (typically framed in the literature as "underrepresented groups"), gender has been a frequent point of comparison, as there has been a focus on the fact that female bodies have historically outnumbered male bodies in U.S. study abroad programs (Picard et al 2009; Fischer 2012; Salisbury et al 2010; Dessoff 2006; Redden 2008; Shirley 2006; Kim and Goldstein 2005; Bloomfield 2004). Meanwhile, there has been a growing concern over the lower participation of differently-abled bodies (Sygall 1995; Hameister et al 1999; Dessoff 2006; Katz 2007) and gay, lesbian, bisexual and transgendered bodies (Pattison 2010; Rubin 2004), as well as bodies from outside traditional four year institutions (Frost and Raby 2009; Stallman et al 2010; Zhang 2011), the humanities, social sciences and business (Hembroff and Rusz 1993; NAFSA 2003; Twombly et al 2012).

Yet, it is the categorization of bodies of participants by race/ethnicity that either wholly or partially marks current literature on study abroad participation. This practice of categorizing study abroad participants by race/ethnicity coincides with the call at the opening address of the $43^{\text {rd }}$ International Conference on Educational Exchange (CIEE 1991) by then-President of Spelman College J.B. Cole to track and monitor the participation of U.S. racial/ethnic minority students in study abroad and the move in 1993 by the Institute of International Education (IIE) to publish this data. These actions have resulted in the practice of framing study abroad participation by race/ethnicity by much of the literature focused on promoting and democratizing U.S. undergraduate study abroad participation, 
adopting the familiar (though not unproblematic) U.S. racial/ethnic categories: white/Caucasian, black/African American, Asian/Native Hawaiian/Pacific Islander, Hispanic/Latino, American Indian/Alaska Native, and multiracial. This body of literature includes institution and government reports (NAFSA 2003; The Lincoln Commission 2005; IIE 2011), trade articles (Craig 1998; Brown 2002; Jackson 2005; Dessoff 2006; Redden 2007; Redden 2008; Norton 2008; Shih 2009; Schmidt 2010; Wilson-Oyelaran 2011) and peer-reviewed journal articles (Van Der Meid 2003; Comp 2008; Penn and Tanner 2009; Brux and Fry 2010; McClure et al 2010; Salisbury et al 2011; Simon and Ainsworth 2012). It additionally includes a number of published/unpublished dissertations, edited books and monographs (Hembroff and Rusz 1993; Washington 1998; Perdreau 2000; Landau and Moore 2001; Picard et al 2009; Wanner 2009; Stallman et al 2010; Twombly et al 2012). Within this literature, the underrepresentation of racial/ethnic minority students in U.S. study abroad has been repeatedly documented and presented as a problem to be addressed, as expressed in the following statement:

... racial and ethnic minorities account for only $17.2 \%$ of all U.S. students studying abroad (IIE 2008) although they comprise approximately $22 \%$ of the college population (National Center for Education Statistics, 2006b). (Stroud 2010: 493)

Though a number of task forces, coalitions, special interest groups and scholarship programs have been created to address the underrepresentation of racial/ ethnic minority student in U.S. study abroad, the gains such efforts have produced in the enrollment and representation of these students in study abroad have been described as "very disheartening" (Shih 2009). This "disheartening" level of participation has been attributed to a number of factors: lack of information about study abroad and the process of applying to programs (Van Der Meid 2003; Shih 2009; Brux and Fry 2010; McClure et al 2010; Stallman et al 2010); lack of structural support/encouragement from faculty and other peers (Cole 1991; Washington 1998; Perdreau 2000; Penn and Tanner 2009; Shih 2009; Brux and Fry 2010; Bruce 2012; Simon and Ainsworth 2012); lack of motivation/limited commitment to international education on the part of students (Brown 2002; Van Der Meid 2003; Dessoff 2006; Shih 2009; Brux and Fry 2010; Salisbury et al 2011); inadequate preparation in foreign languages/curricular requirements on campus (Van Der Meid 2003); cultural barriers/fears of racism (Desruisseaux 1992; Hembroff and Rusz 1993; Carroll 1996; Craig 1998; Perdreau 2000; Brown 2002; Jackson 2005; Redden 2008; Brux and Fry 2010; Gaines 2012) and funding concerns (CIEE 1988; Cole 1991; Hembroff \& Rusz 1993; Washington, 1998; NAFSA 2003; Dessoff 2006, Redden 2008; Shih 2009; Salisbury et al 2011). Over time, these factors have come to be viewed as obstacles to study abroad participation that uniquely and specifically affect racial and ethnic minority students. 


\subsection{The thought that bears the stamp of our age and our geography}

How is it that participation by race/ethnicity has surfaced as such a prominent discourse in the pursuit to promote and democratize study abroad, particularly given field-wide recognition of the multiple categories of underrepresented students - males, community college students, science, technology, engineering and mathematics (STEM) students - associated with U.S. study abroad? In analyzing the discourses and practices that comprise the literature on study abroad participation by racial/ethnic minority students, a resemblance to an existing discourse within U.S. education and with its established set of practices is revealed - that of racial/ethnic disparity. The discourse of racial and ethnic disparity is a longstanding theme in education in the U.S. Disparity, as a stand alone term, is defined as "difference" in the sense of "dissimilarity" (Oxford English Dictionary 2013), and it is often evoked through terms like "underrepresentation", "gap", "discrepancy", "disproportional", and even "(in)equity". However, when the term is paired with the descriptor "racial/ethnic" and combined with specific discursive practices and politicized solutions designed to address educational inequities, its usage adopts a less neutral, more comparative significance - one in which racial/ethnic minority groups do not simply exhibit differences (due to differing local knowledge, priorities, and goals as a community), but do so relationally and disproportionally to a normalized, Caucasian American population. This is just one of several "truths" that have come to be known within the discourse of racial/ethnic disparity. Others include, for example, the understanding that, although the effects of racial/ethnic disparity surface differently among the various racial/ethnic minority groups, all racial/ethnic minorities are affected by this disparity. An additional "truth" rests upon the idea that though socioeconomic status (SES) differences exist within racial/ethnic minority groups, the primacy of a shared racial identity is assumed to override any differences in social practices that might arise due to differing SES; thus, any differences observed within racial/ ethnic minority groups are often erased or minimized. In addition to the previously identified "truths," the discourse of racial/ethnic disparity is associated with and dispersed through practices which "organize and codify ways of doing ... [and] involve the government of conduct, whether of self or others" (Dean 1992: 216). These practices likewise ignore intragroup differences and are often implemented to intervene in the social practices of racial/ethnic minorities as a unified population, rather than as distinct groupings. The "truths" and practices associated with the discourse of racial/ethnic disparity have so embedded themselves in U.S. higher education that their appearance in the body of literature that problematizes study abroad participation by race/ethnicity alludes to the 
presence of an episteme - a "fundamental code[ ] of a culture ... [that governs] its language, its schemas of perception, its exchanges ...” (Foucault 1970[1966]: xx) - concerning race/ethnicity that represents "[t]he thought that bears the stamp of our age and our geography” (Foucault 1970[1966]: xv). This “code” organizes and orders what is known about racial/ethnic minority students. It governs the rules and regularities upon which statements about these students are made and rendered meaningful, and it ranks, monitors, and attempts to control their actions through institutionalized and politicized solutions (realized through the establishment of task forces, special committees, legislation, policies, quotas and benchmarks) enacted to intervene on their behalf and address their perceived needs. It is this "code" which has given rise to the discourse and practices that have enabled a problematization of U.S. study abroad participation by race/ ethnicity.

Such a discursive process, however, is not without material and subject effects - especially towards its objects of study. In the next section, both the process and effects of this problematization will be addressed by 1) problematizing (that is, thinking critically about, foregrounding, and when necessary, countering) the obscured and taken-for-granted truths, assumptions, and practices that mark an approach to study abroad participation by race/ethnicity, 2) decolonizing (Smith 1999) these patterns of understanding and representing difference, and 3) countering these with ways of knowing and experiencing the world local to racial/ethnic minority students in order to privilege and legitimize their often "excluded, unheard, ... [and] disenfranchised" voices (Gilmore and Smith 2005: 70).

\section{Problematizing study abroad participation by race/ethnicity}

\subsection{Uniquely and specifically a minority problem}

The first step in recognizing the process and effects of a problematization of study abroad participation by race and ethnicity is to think critically about the primary claim expressed in the literature: that a problem exists with the participation levels of racial/ethnic minority students in U.S. study abroad that is unique and specific to these groups. This "problem" is framed in the literature principally as a failure by these students to participate in study abroad 1) at levels proportional to the increased growth in study abroad enrollment observed in the U.S. since the 1990s (Perdreau 2000; Comp 2008; Redden 2007, 2008; McClure et al 2010; 
Wilson-Oyelaran 2011) or 2) at percentages comparable to their percentage of enrollment in U.S. higher education (Washington 1998; The Lincoln Commission 2005; Kasravi 2009; Picard et al 2009; Shih 2009; McClure 2010; Wilson-Oyelaran 2011). This latter pattern of framing differences in study abroad participation levels is observed in the following quote:

... the gap between white and minority students in study abroad has widened over the past decade, as the share of minority students studying abroad has grown at a much slower pace than minority students' share of overall college enrollment. (Schmidt 2012).

The problem is additionally presented in the literature using language that draws upon colonized ways of representing data through binary oppositional comparisons of racial/ethnic minorities to their Caucasian counterparts, as evidenced in the statement cited above - “... the gap between white and minority students ...” (Schmidt 2012). Such oppositions imply both a hierarchical relationship between these two groups (suggested in the ordering of the opposing features where "white" is typically listed in the lead position, followed by "minority") and a relational/positional relationship of markedness and normality (unmarked/ normal versus marked/problematic). However, the absence of an expected comparison can also foreground binary oppositions, as in those cases where the participation data for racial/ethnic minority students is directly cited, while that of white students is only indirectly mentioned or is left to be deduced, as seen in the following statement:

In 2005 minority students made up 32 percent of all undergraduates, says the U.S. Education Department. But they accounted for only $17 \%$ of undergraduates who studied abroad in 2005/2006, an increase of barely 1.5 percent over a decade ago, according to the Institute of International Education. (Norton 2008).

This practice of drawing attention to the study abroad participation levels of racial/ethnic minority students and obscuring those of white students has the effect of normalizing the participation of white students, establishing as problematic those of racial/ethnic minority students, and positioning failure to participate in study abroad as uniquely and specifically a racial/ethnic minority phenomenon.

When study abroad participation data for white students is explicitly provided, the data is frequently presented as a percentage of the total U.S. study abroad population - a statistic which though decreasing slightly has measured upwards of $80 \%$ over the last decade (IIE 2011). Presenting the study abroad participation of white students in this way highlights their overrepresentation in study abroad and generates the impression that these students participate in study abroad at much greater levels than racial/ethnic minority students. Yet, 
this tactic of emphasizing the overrepresentation of white students in U.S. study abroad obscures a significant reality: the rate at which these students participate in study abroad as a percentage of their total enrollment in U.S. higher education is less than $2 \%$. In fact, in 2009/2010 the rates of participation across racial/ethnic groups were as follows: 1.67\% (white/Caucasian), 1.60\% (Asian/Pacific Islander), $.68 \%$ (Hispanic/Latino), .65\% (American Indian/Alaska Native) and .44\% (black/ African American). Given the relatively low participation rates across all racial/ ethnic groups, to present failure to participate in travel abroad as uniquely and specifically a racial/ethnic minority problem obscures the fact that failure to participate in study abroad is an American problem, albeit one differentially represented across U.S. racial and ethnic groups. ${ }^{4}$

\begin{tabular}{|l|c|l|c|l|l|}
\hline Race/Ethnicity & $\begin{array}{l}\text { U.S. Higher } \\
\text { Ed Enrollment } \\
\text { (NCES5 2010) }\end{array}$ & $\begin{array}{l}\text { \% U.S. Higher } \\
\text { Ed (NCES 2010) }\end{array}$ & $\begin{array}{l}\text { U.S. Study } \\
\text { Abroad } \\
\text { Enrollment } \\
\text { (IIE 2011) }\end{array}$ & $\begin{array}{l}\text { \% Study } \\
\text { Abroad } \\
\text { (IIE 2011) }\end{array}$ & $\begin{array}{l}\text { Rate of } \\
\text { Participation }\end{array}$ \\
\hline White/Caucasian & $12,730,780$ & $62.3 \%$ & 212,965 & $78.7 \%$ & $1.67 \%$ \\
\hline $\begin{array}{l}\text { Black/African } \\
\text { American }\end{array}$ & $2,919,826$ & $14.3 \%$ & 12,718 & $4.7 \%$ & $.44 \%$ \\
\hline Hispanic/Latino & $2,546,710$ & $12.5 \%$ & 17,319 & $6.4 \%$ & $.68 \%$ \\
\hline $\begin{array}{l}\text { Asian/Native } \\
\text { Hawaiian/Pacific } \\
\text { Islander }\end{array}$ & $1,337,671$ & $6.5 \%$ & 21,378 & $7.9 \%$ & $1.60 \%$ \\
\hline $\begin{array}{l}\text { American } \\
\text { Indian/Alaska } \\
\text { Native }\end{array}$ & 207,917 & $1.0 \%$ & 1,353 & $.5 \%$ & $.65 \%$ \\
\hline Multiracial & NA & NA & 5,141 & $1.9 \%$ & NA \\
\hline
\end{tabular}

Fig. 1: Rates of Participation in U.S. Study Abroad by Race/Ethnicity (2009/2010)

4 Other scholars have begun to consider participation beyond percentage representations by race/ethnicity in study abroad, examining their rates of participation in relation to their enrollment numbers in U.S. higher education (cf. Gore 2005; Comp 2008: 33-34; NAFSA 2011). 5 Data provided by the National Center for Education Statistics (NCES 2010) is based on Fall enrollment in degree-granting institutions, which includes U.S. higher education institutions that grant Associate's or higher degrees and participate in U.S. Title IV financial aid programs. These figures do not add up to $100 \%$ because data for 'nonresident alien' students has not been included in this chart. 


\section{2 "The minority population"}

The next step in exploring the process and effects of a problematization of study abroad participation by race and ethnicity involves foregrounding the taken-forgranted discursive practices that mark the problematization of study abroad participation by race/ethnicity. These practices consist primarily of the adoption of essentialized racial/ethnic categories that erase the socioeconomic, historical and political variability across and within racial/ethnic groups and obscure the potential relevance of these factors on student engagement with different educational practices. For example, though the salience of racial/ethnic identity can be negotiated in social interactions, the adoption of such static categories in tracking undergraduate participation in study abroad is often justified as a way to "monitor progress in broadening the involvement of students of color in overseas educational exchange” (Cole 1991: 1-2). However, this practice presupposes and imposes the primacy of racial/ethnic identity in shaping attitudes toward and participation in study abroad. Racial/ethnic identity "is only one identity from a multitude of social identities, many of which can be relevant simultaneously" (Firth and Wagner 1997: 292); gender, SES, generational status, and parents' level of education may represent aspects of social identity equally or even more likely to influence participation in study abroad (Van Der Meid 2003; Salisbury et al 2011). Without more emic-oriented studies exploring how, when, or even if, race and ethnicity impact decisions to study abroad, it is not possible to truly determine the relationship between race/ethnicity and rates of participation in study abroad.

An additional practice includes the presentation of essentialized racial/ ethnic categories in binary oppositions where the disempowered "other" is researched and written about as an oversimplified, racially/ethnically homogeneous, politically unproblematic population - "the minority population" (Cole 1991: 2). This practice of discursively treating the categories of racial/ethnic minorities en masse erases important differences between these groups, such as the marked difference in participation rates between African Americans and Asian/Pacific Island Americans (see Figure 1). Likewise, it obscures similarities that exist across the minority/majority divide, such as the comparable levels of study abroad participation among Asian/Pacific Island Americans and Caucasian Americans, or the observed correlation between parents' level of education with intent to study abroad for Caucasian, African American and Hispanic students, but not Asian/ Pacific Island American students (Salisbury et al 2011). Such findings "underscore[ ] the critical importance of continuing to study distinct groups separately and in terms of their own 'situated contexts' ..." (Salisbury et al 2011: 144).

Finally, this practice of presenting racial/ethnic minorities collectively erases differences that exist within U.S. racial/ethnic populations due to the diverse 
ethnic compositions that make up these groups. This diversity reflects distinct waves of immigration and settlement, as well as regions and countries of origin, all of which have contributed to patterns of difference among same-race ethnicities in relation to attitudes toward travel and study abroad, educational achievement and engagement in educational practices (Doan 2002; Van Der Meid 2003). Furthermore, this practice obscures the social categories (SES, gender, generational status) recognized on an intra-ethnic level that influence local social identities, as well as engagement with and adoption of social practices (Kobayashi 2008: xii). An example of the multiple levels of difference that can exist within a U.S. racial category is expressed in the following passage:

The Asian American category encompasses a broad and varied range of populations from fourth-generation, upper-middle-class Japanese Americans to newly arrived Southeast Asian refugees on welfare. ... In addition, interethnic and interracial unions are increasing, especially among Asian Americans, calling into question the notion of mutually exclusive groups. (Lott, 1998: 27-28 cited in Van Der Meid, 2003: 72).

Though the above observation concerns the U.S. population of Asian/Pacific Island Americans, similar statements can be made across racial/ethnic groups within the U.S. where, for instance, the racial category of "white/Caucasian" consists of people groups from Europe, the Middle East and North Africa, and "black/ African American" of the descendents of enslaved and freed Africans, to more recent immigrants from Haiti, the Caribbean and various countries of subSaharan Africa (U.S. Census Bureau 2013). ${ }^{6}$

\subsection{Defining, measuring and solving the problem}

A final step in exploring the process and effects of a problematization of study abroad participation by race and ethnicity includes countering the discourses adopted in the literature that define, measure, and shape the solutions to a problematization of study abroad participation by race/ethnicity. Though the problem has been framed as an inability of racial/ethnic minorities to keep pace with the increased levels of study abroad participation observed among white students, it has been defined and measured metaphorically in terms of "barriers" (financial), "constraints" (educational) and "lack" (of interest, awareness, structural sup-

6 The two other major racial/ethnic categories recognized in the U.S., Hispanic/Latino and American Indian/Alaska Native, are equally diverse, representing people groups originating from numerous regions and Federally recognized tribes. Refer to the U.S. Census Bureau (2013) for details on the definitions and ethnic inclusions within these categories. 
port, and financial ability). The barrier to racial/ethnic minority participation in study abroad most cited in the literature is access to financial capital (CIEE 1988, 1991; Cole 1991; Hembroff and Rusz 1993; Washington, 1998; NAFSA 2003; Stallman et al 2010; Salisbury et al 2011). The perception that lack of financial capital - defined as “an individual's actual or perceived financial resources, such as income or financial aid (Salisbury et al 2010: 617) - poses an obstacle unique to racial/ethnic minority students has lead to an increased availability of aid to these students, most notably through the need-based, federally-funded Gilman International Scholarship, where 62\% of their 2010-2011 awardees were members of racial/ethnic minority groups (Thompson-Jones 2012: 5). However, financial obstacles are in no way limited to racial/ethnic minority students - almost $80 \%$ of all students enrolled full-time in higher education in 2007/2008 receive some form of financial aid (NCES 2011), and white students are as likely to receive aid as any other racial/ethnic minority group (with the exception of Asian/Pacific Island American students who are less likely to take financial aid across all racial/ ethnic groups) (NCES 2011). Moreover, racial/ethnic minority students are just as likely as white students to know about and make use of available financial aid and scholarship monies to pursue study abroad (Hembroff and Rusz, 1993: 21). Finally, even with the increased availability of scholarships and aid, the level of study abroad participation among racial/ethnic minority students has only slightly increased over the past decade, suggesting that financial constraints are not the primary obstacle to achieving higher levels of study abroad participation among these students.

Instead, what is perhaps more relevant to defining, measuring and proposing solutions to address the lower rates of study abroad participation among racial/ ethnic minority students is "fit" of the study abroad program with major/field of study and "relevance" to career/academic goals (Doan 2002; Van Der Meid 2003; Penn and Tanner 2009). In this sense, metaphors of "possessing” (such as possessing competing academic priorities) and "having" (having differing educational goals) more accurately describe the factors that differentially shape study abroad decisions among groups of students. They also more aptly reflect a student's orientation toward study abroad as being shaped, not by the financial capital to which a student has access, but by the symbolic capital a student values and/or possesses. Bourdieu defines symbolic capital as the cultural and social value that accrues from the engagement in practices and access to resources not primarily recognized as economic, but which provide social and economic power to those who engage in and possess such practices/resources (Bourdieu 1986). A student's orientation toward symbolic capital reflects not only whether that student will find value in study abroad as part of their educational experience, but whether the student will posses or seek out the necessary networks to navigate 
the process of participating in a study abroad program. Only a handful of studies explore the role of symbolic capital in intent to study abroad by race/ethnicity; though the topic should be studied further (cf. Salisbury et al 2009; 2012; Simon and Ainsworth 2012).

There are other steps that could be taken to further address the problematization of study abroad participation by race/ethnicity, such as problematizing the type of data studied in the literature. Much of the literature on racial/ethnic minority student participation in study abroad overwhelmingly emphasizes students who do not participate in study abroad rather than those who do, thus failing to better understand the factors students across races/ethnicities share who participate in study abroad. It also fails to address the underrepresentation of African American, Latino/Hispanic and American Indian/Alaska Native students at the U.S. institutions that traditionally send students abroad (Liberal Arts Colleges and private institutions) and their overrepresentation at community colleges, Historically Black Colleges and Universities and other Minority Serving Institutions, which are less likely to have or encourage study abroad programs (Akomolafe 2000; Salisbury et al 2009; Gaines 2012). Still, these initial problematizing steps uncover key discourses and practices that underlie the problematization of study abroad participation by race/ethnicity and mark much of the current literature in this area. They reveal how this problematization is centered upon an underlying order of thought based on a discourse of racial/ethnic disparity and they highlight the material effects this discourse and its associated practices have on institutional and governmental policies, the allocation of scholarships and aid, and the development of recruitment materials targeting underrepresented groups. In addition, they uncover the subject effects of these discourses and practices that shape the way the study abroad participation of all students comes to be viewed in the field. However, racial/ethnic minority students in particular are negatively affected, in multiple ways, by this problematization - not only is their participation in study abroad positioned as problematic, but they themselves are subjected to practices that impose race/ethnicity as their primary identity inscription while erasing other potentially relevant socioeconomic, historical and political-related identities and to discourses that describe their level of engagement with practices in terms of barriers, constraints and lack.

Are there, however, other ways of knowing U.S. racial/ethnic minority students and their participation in study abroad? How else might their lower levels of participation be understood beyond metaphors of barriers, constraints and lack? The next section considers just this for black/African American students who, with a rate of .44\% (2009/2010), exhibit the lowest rate of study abroad participation of all other racial/ethnic groups. Since many of the factors that the literature cites as barriers to study abroad participation are shared to varying de- 
grees across racial/ethnic categories (see section 2.1 for a list of such barriers), the following discussion addresses those factors unique to or which contribute in singular ways to lower rates of study abroad participation among African Americans. Though a growing body of academic work - mostly unpublished dissertations, although there are a few peer-reviewed journal articles - has explored those factors (CIEE 1991; Hembroff and Rusz 1993; Carroll 1996; Washington 1998; Jackson 2005; Salisbury et al 2011; Bruce 2012; Cheppel 2012; Gaines 2012; Simon and Ainsworth 2012), few researchers have incorporated into their analyses the contextualized historical and social realities of African Americans which arguably shape their relationship to space and place in unique ways due to the saliency of race on movement, access to symbolic forms of capital, and identity in the U.S. The following section attempts to expand on this unique relationship to space and place, drawing from the same corpus of study abroad participation literature the discourses raised by African American voices that reflect their shared “... histories, their landscapes, their languages, their social relations and their own ways of thinking, feeling and interacting with the world" (Smith 1999: 28). Admittedly, these discourses are drawn from the same body of literature critiqued in this paper that focuses on and adopts colonizing practices of categorizing U.S. undergraduate study abroad participation by race/ethnicity. Nonetheless, incorporating voices even from this body of literature is a start to identifying the discourses - the beliefs, worldviews, and ways of knowing - held by African Americans that support my argument that this group operates, not from a point of lack, constraint or even external barriers, but from a social, historical and cultural context that differently shapes their relationship to and engagement with travel and study abroad.

\section{Alternative Discourses and Competing Voices}

Travel means different things to different groups. Until modern times, travel was either the exclusive purview of the wealthy, an expensive way to see the best of everything, or the last resort of desperate immigrants, fleeing violence and starvation. Certainly, not all people have happy associations with travel. In the segregated United States, travel for African Americans often meant being called up to serve Uncle Sam in distant wars. In Hispanic families it often meant perilous journeys out of rural poverty undertaken at great risk. (Thompson-Jones 2012: 9).

Associations with travel can differ widely between (and even within) racial/ethnic communities. Within the African American community, travel is associated not only with war, but also with concerns for safety and security. A legacy of displacement through enslavement and regional migration from the segregated South to 
the industrial North, the legal constraints on movement under Jim Crow, and the antagonism of racial profiling have meant that place and movement through space have not always been free, safe, voluntary or desired within this community. Further, in the U.S., race is "an organizing factor of place” (Sorin 2009: 85), where places are racialized (typically white/black) and then deemed safe or unsafe, inviting or hostile. Though travel abroad has meant increased freedom, access to career and professional opportunity, and thus expanded concepts of space and place for select groups within the African American community (most notably pre-Civil War abolitionists, artists, pan-Africanists, and the Black academic elite), for the vast majority of African Americans, these concepts can be far more limited in scope. This reality has contributed to a shared racial identity and participation in practices that are unique to African Americans and which represent knowledge often overlooked in investigating African American perceptions of study abroad. Operating under the premise of race, space and place as organizing factors for African American when considering study abroad, three themes surface from the texts and narratives within study abroad participation literature that suggest a unique influence on African American engagement with study abroad, but which have yet to be addressed in depth. These themes are the legacy of Jim Crow, failure to posses the "right" symbolic capital, and the sentiment that study abroad is "not for people like us". Though these themes are discussed separately below, they are nonetheless (inter)related and overlap in a number of ways.

\subsection{The legacy of Jim Crow}

Though racism and discrimination abroad have the potential to affect students of any race/ethnicity (depending on their background and the country in which they are studying), concern for these two factors in a study abroad setting are expressed in the literature with much greater frequency by African American students than by students of other racial/ethnic heritage (cf. Desruisseaux 1992; Hembroff and Rusz 1993; Carroll 1996; Jackson 2006; Penn and Tanner 2009; Brux and Fry 2010; Gaines 2012). One such expression of concern was expressed by an African American student planning to study in Germany:

I really didn't know what to think. ... I came here worried that everyone was a racist and scared that people would beat me up or shout ugly slogans at me. (Desruisseaux 1992).

Such overt worry about bodily harm is not typically expressed in the literature; rather, what is expressed is recognition of the manner in which reception to one's 
race can "impinge[ ] on ... actions and interactions" (Talburt and Stewart 1999: 164). For a community where Jim Crow Laws and its de jure segregation of public spaces resulted in a de facto designation of spaces/places as off-limits, unsafe and even threatening, it is not surprising that African American students express concerns for racism and discrimination; and though Jim Crow Laws no longer exist in the U.S., their legacy continues through the policing of space (through racial profiling) and in discourses in which space, place and even social practices are racialized in the American imaginary. Yet, the uncertainty expressed by African American students for the impact of race on social interactions is not limited to anticipated contact with the local population. For some, this apprehension extends to the space these students would share with nonblack members of the study abroad community and the fear that racism or racial insensitivity might carry over from home onto the foreign soil, leaving the student in a vulnerable and isolating position. This concern is expressed in the literature as a preoccupation with or awareness of being "the only one". For example:

\footnotetext{
One student expressed concern about being the only Black student in a group of White students studying in another country, and others nodded again in agreement. One student referred to it as a 'double whammy,' meaning that the student would be 'different' from others in the group and different from the people of the host country. (Brux and Fry 2010: 521).
}

In an effort to make study abroad more attractive to African American students (by making race less pertinent, as well as in presenting opportunities for identity/ cultural affiliation), an increasing number of study abroad programs have been launched in countries with ties to the African Diaspora - principally Brazil, Ghana and South Africa (Tucker 1991; Carroll 1996; Szekely 1998; Long 2000; Landau and Moore 2001; Neff 2001; Penn and Tanner 2009). In addition, a case has been made for the benefit to African American students of engaging with communities of African descent within Western European cities (Craig 1998; Comp 2008). However, relying on African American interest in heritage programs will not necessarily expand their rate of participation in study abroad; not all African American students readily identify with modern continental Africa. Furthermore, many of the heritage programs designed to appeal to African American students receive less marketing and promotional emphasis than traditional European destinations, and thus are less well-known (Penn and Tanner 2009). And even if African American students attend these programs, heritage locations present their own challenges regarding race for which these students must be prepared (Tsantir and Titus 2006). 


\subsection{Failure to possess the "right" symbolic capital}

Though much attention is given to the role of financial capital in making study abroad less accessible to racial/ethnic minority students, again, it is the range of symbolic capital that likewise influences the likelihood that a student will participate in study abroad. And though access to symbolic capital is not determined by race, larger socio-political and historical factors have resulted in unequal access to symbolic resources - particular cultural experiences and access to social networks - across racial/ethnic groups in the U.S. In fact, there is a body of study abroad literature that posits that African Americans in particular are at a disadvantage in possessing the symbolic capital necessary to successfully navigate the process of study abroad (CIEE 1991; Hembroff and Rusz 1993; Washington 1998; Brown 2002; Penn and Tanner 2009; Shih 2009; Brux and Fry 2010; Bruce 2012; Simon and Ainsworth 2012). For example, it is suggested that these students tend to begin their secondary education with less overall international travel experience than members of other racial/ethnic groups (Hembroff and Rusz, 1993; Watterson 2011 citing Lassiter 2003) and therefore have a smaller network of travelers (faculty, friends, peers) from whom they can draw support and encouragement to study abroad (Hembroff and Rusz 1993). Penn and Tanner suggest that specifically what is lacking is knowledge about how to "make [study abroad] a part of the college experience" (2009: 278); that is, which study abroad programs to pursue, what educational requirements must be met, what travel and institutional documents are needed, what sources of funding are available to support study abroad, and most important, how to fit study abroad into their overall educational goals. As expressed in the following statement, these networks could also prepare African American students for the unique challenges of negotiating "meanings of race and gender in the context of study abroad, their impact on students' access to and interactions with members of the host culture, their perceptions of the country they are visiting, and their learning experiences" (Talburt \& Stewart 1999: 2):

I was kind of hesitant to ask [about racial issues she might experience as a Black woman in Brazil and Argentina]. I'm just too tentative to ask that question because I thought I would be really stepping out of the bounds.... I was looking at the significance of actually talking about [racism]. (Allison, interviewed in Simon and Ainsworth 2012: 14).

Further, the continued association of study abroad with the accumulation of symbolic capital may likewise pose an obstacle for some African American students. Despite government and institutional policies that promote the benefits of study abroad to national security and workforce preparedness, discourses tied to 
the "Grand Tour" image of study abroad persist (Gore 2005; Jackson 2005; Michelson and Alvarez 2012). This image draws upon a discursive tradition that romanticizes (and thus bestows symbolic capital towards) the sending of young white women abroad for leisure and/or personal fulfillment; an image reinforced through a number of online study abroad promotional websites (Michelson and Alvarez 2012) and media images (Jackson 2005) - most recently encountered in the young adult films "Passport to Paris" (1999), "Winning London" (2001), "When in Rome” (2002), "The Lizzie McGuire Movie” (2003), and "Eurotrip" (2004). This discursive tradition excludes multiple segments of potential study abroad students who may fail to identify with these images and discourses, with racial/ethnic minorities (and African Americans in particular) particularly vulnerable to seeing themselves outside this discourse and the symbolic capital associated with these images of study abroad. These students would benefit from the support of faculty and peers who could help them navigate these discourses, or even create new, or tap into existing discourses that are more inline with the symbolic values of their community or family.

\subsection{Not for people like us}

Though research supports the view that African American students find study abroad a "desirable and realistic part of their educational experience" (Gaines 2012: 58), a recurring discourse of exclusion surfaces in the literature among these students that study abroad is "not for people like me" (Jackson 2005: 16; Craig 1998; Brown 2002; Hardaway 2010; Gaines 2012). Evidence of this discourse is apparent in the following statement made by First Lady Michelle Obama, who references her "blue collar" (socioeconomic status) and "South Side of Chicago" (race) roots:

I understand these feelings. I felt the same way when I was back in college. I grew up in a blue collar neighborhood on the South Side of Chicago, and the idea of spending time abroad just never registered with me. My brother and I were among the first in our families to go to college. So trust me, we were way more focused on getting in, getting through, and getting out than we were with finding opportunities that would broaden our horizons (First Lady Michelle Obama, Mertz 2011 cited in Thompson-Jones 2012: 2).

One reason for this discourse of exclusion is that movement across borders even in the imaginary - can introduce students to discourses, interactions and experiences that conflict with, constrain or even deny some aspect of that individual's identity (Shardakova and Pavlenko 2004; Block 2007; Pavlenko and Norton 2007). For example, given that African American students may be more 
like as a group to have traveled abroad less prior to going to college (Hembroff and Rusz 1993), their members may more readily lack "traveler" as part of their social identity. If this is indeed the case, then lack of prior travel experience is potentially a significant handicap for African American students, as "[s]tudents whose families travel abroad and are more comfortable with foreign cultures are more likely to see study abroad programs as appropriate for themselves and/or relevant to their educational goals" (Simon and Ainsworth 2012: 8).

In addition, many of the discourses associated with study abroad are associated with images of whiteness and privilege (Gore 2005) and notions of reconnecting with ancestral roots (Jewitt 2010), discourses which in particular may conflict with African American identity and historical experience, disenfranchisement, and forced separation from ancestral ties. The view of study abroad as an economic and racialized activity is incredibly strong. For example:

The perception of study abroad as reserved for rich, white students is difficult to challenge.... Google 'study abroad' and one of the top hits is from a blog called Stuff White People Like. (Norton 2008).

These images exist in the American imaginary about study abroad, particularly study abroad to Europe, presenting "oversimplified and stereotyped identity options" that are reproduced and recirculated through textbooks (Shardakova and Pavlenko 2004: 27), popular media (Jackson 2005), print and merchandising materials (Jewitt 2010), and online resources (Michelson and Alvarez 2012). Though the Europe that exists in the American imagination may have less in common with the present reality of an increasingly racially and ethnically diverse Europe, the ways in which study abroad are marketed (the dearth of recruitment material that reflects the racial/ethnic diversity that comprises modern Europe, and the continual Eurocentric images projected through popular media) perpetuate an image and discourse about study abroad that erases non-whites, as well as whites who do not strongly identify with such images, and denies people of color access to this imagined community. However, African Americans are particularly shut out of this discourse due to race and a more distant connection to a non U.S. homeland than even other members of U.S. racial/ethnic minority groups. It is this exclusion from the discourse of study abroad that results in the perception that study abroad is "not for people like us" and potentially dissuades African American interest in participation in study abroad. Fortunately, concepts of race and place shift across space and time, leaving room for an increasing number of African American study abroad returnees and a growing body of travel abroad literature featuring African American protagonists (Angelou 1991; Lee 1997; Lee 2002; Hardaway 2010). This can lead to reterritorializing travel and study abroad 
in the African American imagination as an endeavor that does include "people like us".

\section{Conclusion}

This paper has examined the discourses and practices that underlie the literature in which participation in U.S. study abroad has been problematized by race and ethnicity and the material and subjectivation effects this problematization has on students, institutional and governmental policies and practices, and the allocation of study abroad resources. In problematizing this literature, the aim has not been to downplay the underrepresentation of specific racial/ethnic groups in study abroad; rather it has been to highlight the role discourses circulating about and within racial/ethnic communities play in shaping student participation in study abroad and obscuring more significant challenges within the field to promoting and diversifying student participation in study abroad.

\section{References}

Akomolafe, Olusoji. 2000. Africanizing HBCUs: Problems and prospects of international education in historically Black institutions. Journal of African Issues 28(1-2). 103-107.

Angelou, Maya. 1991. All God's Children Need Traveling Shoes. New York: Vintage Books.

Bacchi, Carol. 2012. Why study problematizations? Making politics visible. Open Journal of Political Science 2(1). 1-8.

Beck, Hamilton. 1996. W. E. B. Du Bois as a study abroad atudent in Germany, 1892-1894. Frontiers: The Interdisciplinary Journal of Study Abroad 2 (Fall). http://www. frontiersjournal.com/issues/vol2/vol2-03_Beck.htm.

Block, David. 2007. The rise of identity in SLA research, post Firth and Wagner. The Modern Language Journal 91. 863-876.

Bloomfield, Steven. 2004. One man at a time. NAFSA: Underrepresentation in Education Abroad Newsletter 1. 3-4.

Bourdieu, Pierre. 1986. The forms of capital. In John G. Richardson (ed.), Handbook of theory and research for the sociology of education, New York: Greenwood.

Brown, Linda. 2002. Going global. Black Issues in Higher Education 19(6). 28-31.

Bruce, Aaron. 2012. Beyond the Black horizon: Perspectives of African American collegians who studied abroad. Dissertations and Graduate Research Overview, paper 55. MA thesis.

Brux, Jacqueline Murray \& Blake Fry. 2010. Multicultural students in study abroad: Their interests, their issues, and their constraints. Journal of Studies in International Education 14(5). 508-527.

Carroll, Allison V. 1996. The participation of historically underrepresented students in study abroad programs: An assessment of interest and perception of barriers. Colorado State University, Fort Collins. MA thesis. 
Cheppel, Alena. 2012. A phenomenological study of undergraduate African American college students' decision to participate in study abroad. University of Phoenix. ProQuest, UMI Dissertations Publishing. 3531377.

Cole, Johnnetta. 1991. Opening address of the 43rd International Conference on Educational Exchange. In Black students and overseas programs: Broadening the base of participation. 1-5. New York, NY: Council on International Educational Exchange (CIEE).

Commission on the Abraham Lincoln Study Abroad Fellowship Program. 2005. Global competence and national needs: One million Americans studying abroad. Washington DC.

Comp, David. 2008. U.S. heritage-seeking students discover minority communities in Western Europe. Journal of Studies in International Education 12(1). 29-37.

CIEE, Council on International Educational Exchange.1988. Educating for Global Competence: The Report of the Advisory Council for International Educational Exchange. http://www. ciee.org/research_center/archive/Global_Competence/1988GlobalCompReport.pdf.

CIEE, Council on International Educational Exchange. 1991. Black students and overseas programs: Broadening the base of participation. New York, NY: Council on International Educational Exchange (CIEE).

Craig, Starlett. July/August 1998. Study abroad adviser: Top 10 reasons for African American students to go abroad. Transitions Abroad 10. 89-91. http://www.transitionsabroad.com/ listings/study/articles/studyjul1.shtml.

Dean, Mitchell. 1992. A genealogy of the government of poverty. Economy and Society 21(3). 215-251.

Desruisseaux, Paul. 25 November 1992. Abroad, Minority Students' Challenges Transcend Academics. The Chronicle of Higher Education 39(14). A 27.

Dessoff, Alan. 2006. Who's not going abroad? International Educator 15(2). 20-27.

Doan, Thuý. 2002. Asian American students: Study abroad participation, perspectives and experiences. University of Minnesota, Minneapolis, MN. MA thesis.

Evans, Stephanie. 2009. African American women scholars and international research: Dr. Anna Julia Cooper's legacy of study abroad, Frontiers: The Interdisciplinary Journal of Study Abroad vol. 2. 77-100.

Firth, Alan \& Johannes Wagner. 1997. On Discourse, Communication, and (Some) Fundamental Concepts in SLA Research. The Modern Language Journal 81(3). 285-300.

Fischer, Karin. 24 February 2012. Colleges are urged to try new approaches to diversify study abroad. The Chronicle of Higher Education 85(25). A1-A14. http://chronicle.com/article/ Colleges-Are-Urged-to-Try-New/130908.

Foucault, Michel. 1970. The order of things: An archaeology of the human sciences. Vintage Books Edition, 1994. New York, NY: Vintage Books. Original work published 1966.

Foucault, Michel. 1984. Polemics, Politics and Problematizations: An Interview with Michel Foucault. In Paul Rabinow, Nikolas Rose, \& Michel Foucault (eds.), The essential Foucault: Selections from essential works of Foucault, 1954-1984. New York: New Press. http://foucault.info/foucault/interview.html.

Foucault, Michel. 1988. The concern for truth. In Lawrence Kritzman (ed.), Politics, philosophy, culture: Interviews and other writings, 1977-1984. Alan Sheridan and others, trans. New York and London: Routledge.

Frost, Robert A. \& Rosalind L. Raby. 2009. Democratizing study abroad: Challenges of open access, local commitments, and global competence in community colleges. In Ross Lewin (ed.), The handbook of practice and research in study abroad: higher education and the quest for global citizenship, 170-190. New York, NY: Routledge. 
Gaines, Nykia. 2012. Exploring the perceptions of study abroad among black undergraduates at historically black colleges and universities. Bowling Green State University, ProQuest, UMI Dissertations Publishing. 3510805.

Gilmore, Perry \& David Smith. 2005. Seizing academic power: Indigenous subaltern voices, metaliteracy, and counternarratives in higher education. In T. L. McCarty (ed.), Language, literacy, and power in schooling. 67-86. Mahwah, NJ: Lawrence Erlbaum.

Gore, Joan E. 2005. Dominant beliefs and alternative voices: Discourse, belief, and gender in American study abroad. New York and London: Routledge.

Hameister, Brenda, Peter Matthews, Nathaniel Hosley, \& Margo Groff. 1999. College students with disabilities and study abroad: Implications for international education staff. Frontiers: The Interdisciplinary Journal of Study Abroad, vol. 5. 81-100.

Hardaway, Jheri. 2010. M.E.E.T me for cheese and chocolate: My European experiences and travel. Bloomington, IN: Xlibris.

Hembroff, Larry A. \& Debra L. Rusz. 1993. Minorities and overseas studies programs: Correlates of differential participation. Volume 30 of occasional papers on international educational exchange: Research series. New York, NY: Council on International Educational Exchange.

IIE, Institute of International Education. 2011. Open Doors Report: Profile of U.S. study abroad students 2000/01-2009/10, report on International Educational Exchange. http://www.iie.org/opendoors.

Jackson, Marilyn J. 2005. Breaking the barriers to overseas study for students of color and minorities. IIENetworker Magazine: Diversity in international education. http://www. articlesbase.com/international-studies-articles/breaking-the-barriers-to-overseas-studyfor-students-of-color-and-minorities-4516037.html.

Jackson, Marilyn J. 2006. Traveling shoes: Study abroad experiences of African American students participating in California State University international programs. The University of San Francisco, ProQuest, UMI Dissertations Publishing. 3227519.

Jewitt, Sarah. 2010. "We're Sort of Imposters": Negotiating identity at home and abroad. Curriculum Inquiry 40. 635-656.

Kasravi, Jinous. 2009. Factors influencing the decision to study abroad for students of color: Moving beyond the barriers. The University of Minnesota, ProQuest, UMI Dissertations Publishing. 3371866.

Katz, Eve. 2007. Students with disabilities studying abroad. International Educator. 52-57.

Kim, Randi \& Susan Goldstein. 2005. Intercultural attitudes predict favorable study abroad expectations of U.S. college students. Journal of Studies in International Education 9(3). 265-278.

Kobayashi, Satoko. 2008. Labeling groups and space: Discourse and spatial positioning of social identity among transnational Japanese high school students. University of California, Santa Barbara, ProQuest, UMI Dissertations Publishing. 3319803.

Landau, Jennifer \& David Chioni Moore. 2001. Towards reconciliation in the motherland: Race, class, nationality, gender, and the complexities of American student presence at the University of Ghana, Legon. Frontiers: The Interdisciplinary Journal of Study Abroad 7. 25-59.

Lee, Andrea. 2002. Interesting Women: stories. New York: Random House.

Lee, Elaine. 1997. Go Girl!: The Black woman's book of travel and adventure. Portland, OR: The Eighth Mountain Press.

Lewin, Ross. 2009. Introduction: The quest for global citizenship through study abroad. In Ross Lewin (ed.), The handbook of practice and research in study abroad: Higher education and the quest for global citizenship. xii-xxii. New York and London: Routledge. 
Long, John. 2000. German studies and minority communities. The German Quarterly 73(1). 19-20. Lott, Juanita. 1998. Asian Americans: From racial category to multiple identities. Walnut Creek, CA: Altamira Press.

McClure, Kevin, Katalin Szelényi, Elizabeth Niehaus, Aeriel Anderson \& Jeffrey Reed. 2010. We just don't have the possibility yet: U.S. Latina/o narratives on study abroad. Journal of Student Affairs Research and Practice 47(3). 367-386.

Michelson, Kristen \& Jose Alvarez. 2012. Examining discourses of study abroad: The case of promotional websites. Third International Conference on the Development and Assessment of Intercultural Competence. http://cercll.arizona.edu/_media/development/ conferences/2012_icc/session_11_michelson_and_alvarez.pdf.

NAFSA: Association of International Educators. 2003. Internationalizing the campus: Profiles of success at colleges and universities. Washington, DC: NAFSA. http://www.nafsa.org/_/ file/_/itc2003.pdf.

NAFSA: Association of International Educators. 2011. A Global Education: No Longer OptionalStudy Abroad Statistics, 2009/2010. http://www.nafsa.org/uploadedFiles/NAFSA_Home/ Resource_Library_Assets/Public_Policy/Study\%20Abroad\%20Demographics.pdf.

NCES, National Center for Education Statistics. Spring 2010. Table 240: Fall Enrollment in degree-granting institutions by race/ethnicity and state jurisdiction: 2009 (Total United States). U.S. Department of Education, National Center for Education Statistics, Integrated Postsecondary Education Data System (IPEDS). http://nces.ed.gov/programs/digest/d11/ tables/dt11_240.asp.

NCES, National Center for Education Statistics. 2011. Table 353: Percentage of undergraduates receiving aid, by type and source of aid and selected student characteristics: 2007-08.

National Task Force on Undergraduate Education Abroad. 1990. A national mandate for education abroad: Getting on with the task. Washington, DC: NAFSA.

Neff, R. Alex. 2 August 2001. Discovering heritage and more by studying abroad. Black Issues in Higher Education 18. 72. http://diverseeducation.com/article/1560/\#.

Norton, Ingrid. 26 September 2008. Changing the face of study abroad. Colleges reach out to minority students in effort to reduce racial disparities. The Chronicle of Higher Education 55(5).

Oxford English Dictionary. 2013. http://www.oed.com/.

Pattison, Katy. 2010. Lesbian, gay, bisexual, and transgender undergraduate students: access and attitudes to international study. California State University: Sacramento.

Pavlenko, Aneta \& Bonny Norton. 2007. Imagined communities, identity, and English language learning. In Jim Cummins \& Chris Davison (eds.) International Handbook of English Language Teaching. 669-680. Dordrecht, Netherlands: Springer.

Penn, Everette \& Jennifer Tanner. 2009. Black Students and International Education: An Assessment. Journal of Black Studies 40(2). 266-282.

Perdreau, Connie. 2000. Building diversity into education abroad programs. In M. Tillman (ed.), Study abroad: A $21^{\text {st }}$ century perspective, vol. 1. Stamford, CT: American Institute for Foreign Study Foundation. http://www.aifsfoundation.org/perdreau.asp.

Picard, Earl, Farrah Bernardino \& Kike Ehigiator. 2009. Global citizenship for all: Low minority student participation in study abroad - seeking strategies for success. In Ross Lewin (ed.), The handbook of practice and research in study abroad: higher education and the quest for global citizenship. 321-345. New York and London: Routledge.

Pryor, Elizabeth. 2008. Jim Crow, cars, passport denials and Atlantic crossings: AfricanAmerican travel, protest and citizenship at home and abroad, 1827-1865. University of California, Santa Barbara. ProQuest, UMI Dissertations Publishing. 3319792. 
Redden, Elizabeth. 11 June 2007. Study abroad isn’t just for White students. Inside Higher Ed. http://www.insidehighered.com/news/2007/06/11/diversity.

Redden, Elizabeth. 29 May 2008. Diversifying study abroad, the data-driven way. Inside Higher Ed. http://www.insidehighered.com/news/2008/05/29/nafsa.

Rubin, Kyna. Winter 2004. Going “home” to study. International Educator 13(1). 26-33.

Salisbury, Mark, Paul Umbach, Michael Paulsen, \& Ernest T. Pascarella. 2009. Going global: Understanding the choice process of the intent to study abroad. Research in Higher Education 50. 119-143.

Salisbury, Mark, Michael Paulsen, \& Ernest T. Pascarella. 2010. To see the world or stay at home: Applying an integrated student choice model to explore the gender gap in the intent to study abroad. Research in Higher Education 51. 615-640.

Salisbury, Mark, Michael Paulsen, and Ernest T. Pascarella. 2011. Why do all the study abroad students look alike? Applying an integrated student choice model to explore differences in the factors that influence White and minority students' intent to study abroad. Research in Higher Education 52. 123-150.

Schmidt, Peter. 20 September 2010. Race plays key role in decision to study abroad or to stay home, study finds. The Chronicle of Higher Education.

Shardakova, Marya \& Aneta Pavlenko. 2004. Identity options in Russian textbooks. Journal of Language, Identity, and Education 3(1). 25-46.

Shih, Karen. 16 November 2009. Study abroad participation up, except among minority students. Diverse Issues in Higher Education. http://diverseeducation.com/article/13193/.

Shirley, Steven W. 2006. The gender gap in post-secondary study abroad: Understanding and marketing to male students. The University of North Dakota. ProQuest, UMI Dissertations Publishing. 3233968.

Simon, Jennifer \& James W. Ainsworth. 2012. Race and socioeconomic status differences in study abroad participation: The role of habitus, social networks, and cultural capital. ISRN Education. 1-21. http://www.hindawi.com/isrn/education/2012/413896/cta/.

Smith, Linda T. 1999. Decolonizing methodologies: Research and Indigenous peoples. London and New York: Zed Books, Ltd.

Sorin, Gretchen S. 2009. "Keep Going": African American on the road in the era of Jim Crow. State University of New York at Albany. ProQuest, UMI Dissertations Publishing. 3368737.

Stallman, Elizabeth, Gayle A. Woodruff, Jinous Kasravi, \& David Comp. 2010. The diversification of the student profile. In W.W. Hoffa \& S. C DePaul, (eds.), A History of U.S. Study Abroad: 1965- Present. 115-160. A Special Publication of Frontiers: The Interdisciplinary Journal of Study Abroad. Carlisle, PA: Frontiers Journal.

Stroud, April H. 2010. Who plans (not) to study abroad? An examination of U.S. student intent. Journal of Studies in International Education 14(5). 491-507.

Sygall, Susan. 1995. Facilitating exchange: Including persons with disabilities in international programs. Transitions Abroad 18(5). 87-89.

Szekely, B. B. 1998. Seeking heritage in study abroad. In T. Davis (ed.), Open Doors on the Web. New York: Institute of International Education.

Talburt, Susan \& Melissa Stewart. 1999. What's the subject of study abroad?: Race, gender and “Living Culture”. The Modern Language Journal 83. 163-175.

Thompson-Jones, Mary. 2012. Not for kids like me: How the Gilman Program is changing study abroad. University of Pennsylvania. ProQuest, UMI Dissertations Publishing. 3530066 . 
Tsantir, Stacy B. \& Bradley J. Titus. 2006. Heritage-Seeking and Study Abroad: A Case Study. IIE Networker Fall. 27-29.

Tucker, Kelly. 1991. Students speak for themselves: Experiences in Scotland. In Black students and overseas programs: Broadening the base of participation. 35-36. New York: Council on International Educational Exchange.

Twombly, Susan, Mark H. Salisbury, Shannon D. Tumanut, \& Paul Klut. 2012. Study abroad in a new global century: renewing the promise, refining the purpose. ASHE Higher Education Report, 38(4). 1-152. San Francisco, CA: Wiley Subscription Service.

United States Census Bureau. 2013. http://www.census.gov/population/race/about/

Van Der Meid, J. Scott. 2003. Asian Americans: Factors influencing the decision to study abroad. Frontiers: The Interdisciplinary Journal of Study Abroad, 9. http://www. frontiersjournal.com/issues/vol9/vol9-04_vandermeid.htm.

Wanner, Dieter. 2009. Study abroad and language: from maximal to realistic models. In Ross Lewin (ed.), The handbook of practice and research in study abroad: higher education and the quest for global citizenship. 81-98. New York and London: Routledge.

Washington, Donald. 1998. African American undergraduate students' perceptions of and attitudes toward study abroad programs. George Mason University. ProQuest, UMI Dissertations Publishing. 9901923.

Watterson, Katrina. 2011. The attitudes of African American students towards the study of foreign languages and cultures. Louisiana State University and Agricultural and Mechanical College. http://etd.Isu.edu/docs/available/etd-04152011-150931/ unrestricted/totaldiss.pdf.

Wilson-Oyelaran, Eileen B. Spring 2011. Diversity in Education Abroad: A plan for our campuses. IIENetworker. 30-33.

Zhang, Yi L. 2011. CSCC review series: Education abroad in the U.S. community colleges. Community College Review 39(2). 181-200.

\section{Bionote}

M'Balia Thomas is a doctoral candidate in the Interdisciplinary Program of Second Language Acquisition and Teaching (SLAT) at the University of Arizona in Tucson, Arizona, USA. Her research explores linguistic manifestations of power in foreign language education as they relate to larger social contexts of race/ ethnicity, SES, gender and space. 
Copyright of Applied Linguistics Review is the property of De Gruyter and its content may not be copied or emailed to multiple sites or posted to a listserv without the copyright holder's express written permission. However, users may print, download, or email articles for individual use. 